\title{
A List of Blood Parasites of Sea Fish taken at Plymouth.
}

By

\section{Herbert Henry, M.D.}

The following is the result of an investigation with regard to the occurrence of haemoprotozoa in sea fish taken in the neighbourhood of Plymouth :-

A. In May, 1911.

\begin{tabular}{ll|c|c|c|c}
\hline & & $\begin{array}{c}\text { Number } \\
\text { examined. }\end{array}$ & $\begin{array}{c}\text { Number with } \\
\text { haemogrega- } \\
\text { rines. }\end{array}$ & $\begin{array}{c}\text { Number with } \\
\text { trypanosomes. }\end{array}$ & $\begin{array}{c}\text { Number with } \\
\text { new parasites. }\end{array}$ \\
\hline Solea vulgaris & $\cdot$ & 4 & $4^{(1)}$ & - & - \\
Callionymus lyra & $\cdot$ & 15 & $5^{(2)}$ & $1^{(3)}$ & - \\
Cottus bubalis & $\cdot$ & 10 & $2^{(4)}$ & - & - \\
Blennius pholis $\quad$. & $\cdot$ & 6 & $6^{(5)}$ & - & - \\
Gobius pattorugine & $\cdot$ & 1 & - & - & - \\
Agonus cataphractus & $\cdot$ & 9 & $2^{(6)}$ & - & - \\
\hline
\end{tabular}

B. In August-September, 1912.

\begin{tabular}{|c|c|c|c|c|c|}
\hline Pleuronectes platessa & . & 13 & $2^{(9)}$ & - & - \\
\hline Callionymus lyra. & . & 4 & - & - & - \\
\hline Blennius pholis . & . & 2 & $2^{(5)}$ & - & - \\
\hline ,, gattorugine & . & 2 & $2^{(5)}$ & - & - \\
\hline Gobius ruthensparri & . & 5 & - & - & - \\
\hline , minutus. & . & 4 & - & - & - \\
\hline " paganellus. & . & 31 & $3^{(6)}$ & - & - \\
\hline Motella mustela . & . & 9 & - & - & $1^{(10)}$ \\
\hline Cottus bubalis & . & 13 & $2^{(4)}$ & - & - \\
\hline Rhina squatina & . & 5 & - & - & - \\
\hline Solea lutea & . & 6 & $1^{(11)}$ & - & - \\
\hline „, vulgaris & . & 13 & $12^{(1)}$ & - & - \\
\hline Gasterosteus spinachia & . & 8 & - & - & - \\
\hline Scomber scomber . & . & 36 & - & - & $2^{(12}$ \\
\hline Agonus cataphractus & . & 1 & - & - & - \\
\hline $\begin{array}{l}\text { Siphonostoma typhle } \\
\text { Syngnathus acus }\end{array}$ & \} & 12 & - & - & - \\
\hline
\end{tabular}




\section{LIST OF PARASITES WITH REFERENCES.}

(The numbers are the index figures in the above table.)

1. Haemogregarina simondi . . . Laveran et Mesnil, "Deux Hémogrégarines nouvelles des Poissons," Compt. rend. Acad. d. Sc., Paris, 1901, tome exxxiii., p. 572.

2. Haemogregarina quadrigemina . . Brumpt et Lebailly (see ref. 3).

3. Trypanosoma callionymi . . . Brumpt et Lebailly, "Description de quelques nouvelles espèces de Trypanosomes et d'Hémogrégarines de Téléostéens marins," Compt. rend. Acad. d. Sc., Paris, 1904, tome exxxix., p. 613.

4. Haemogregarina cotti . . . . Brumpt et Lebailly (see ref. 3).

5. Haemogregarina bigemina . . . Laveran et Mesnil, 1901 (see ref. 1).

6. Haemogregarina polypartita . . . Neumann, "Studien über protozoische Parasiten im Blut von Meeresfischen," Ztschr. f. Hyg. u. Infectionskrankheiten, Leipzig, 1909, Bd. xiv., Heft 1, S. 1.

7. A Haemogregarine (to be described).

8. A Trypanosome (to be described).

9. Haemogregarina platessae . . . . Lebailly, "Sur quelques Hémoflagellés des Téléostéens marins," Compt. rend. Acad. d. Sc., Paris, 1904, tome exxxix., p. 576.

10. A new parasite (to be described).

11. Haemogregarina clavata . . . . Neumann (see ref. 6).

12. A new parasite (to be described).

All fish were carefully examined for ecto-parasites, as possible carriers of infection, with the following results:-

1. On two specimens of Solea vulgaris, there was found a leech Trachelobdella lubrica? (HARDIng: "A Revision of British Leeches," Parasitology, Cambridge, vol. iii., No. 2, pp. 136-9).

2. On five specimens of Solea vulgaris, there was found a trematode, Phyllonella soleae (Bronn: Das Thierreich, Leipzig, 1879-93. Abth. I A, Bd. iv., S. 363, S. 527).

3. On two specimens of Scomber scomber, a parasitic copepod, Caligus scombri (Basset, Smith: Ann. and Mag. Nat. Hist., 1898, vol. ii., p. 83, pl. 14, fig. 2. Thомas Scotт: "Notes on some Parasites of Fishes," Nineteenth Annual Report of Fishery Board of Scotland, 1901). 


\section{ABSTRACTS OF MEMOIRS}

RECORDING WORK DONE AT THE PLYMOUTH LABORATORY.

\section{Experimental Metaplasia. I. The formation of columnar ciliated epithelium from fibroblasts in Pecten. By G. Harold Drew. (Journal of Experimental Zoology, Vol. X, 1911, pp. 349-379.)}

THE implantation of small pieces of the ripe ovary of Pecten maximus or Pecten opercularis into the adductor muscle of another animal of the same species was found to result at first in the formation of a closed cyst within the muscle, lined with layers of fibroblasts. Complete degeneration and disintegration of the ovarian tissue within the cyst occurred in a few days, and then the cyst contained only an orangecoloured granular substance, presumably derived from the yolk, and numbers of blood corpuscles. After the lapse of from twenty-one to thirty-two days, changes occurred in the innermost layer of fibroblasts lining the cyst. They reverted to an embryonic type, and afterwards became converted into columnar ciliated epithelium, which formed a continuous layer lining the cyst. The changes resulting in this formation of ciliated epithelium from fibroblasts were followed clearly step by step, and once formed, the ciliated cells persisted unaltered for at least 120 days, which was the longest period for which the animals could be kept alive under experimental conditions.

Experiments were performed showing that this change is not produced by the implantation of any of the other tissues of Pecten, by neutral foreign bodies which would merely act as a source of mechanical irritation, by the transplantation of the ripe ovarian tissue of other Lamellibranchs, or by the transplantation of pieces of the ovary of Pecten opercularis into the adductor muscle of Pecten maximus, and vice versa.

Other experiments showed that the development of ciliated epithelium does not occur if pieces of the immature or spent ovary be implanted, and that it is prevented by treating the ripe ovary with a suspension of the sperm in sterile sea-water before implantation. Also that it does not occur if the ovary be killed by physical or chemical agents before implantation. A series of experiments were 
made to eliminate the possibility of the origin of the ciliated epithelium lining the cysts from the ciliated cells of the oviduct, which might be present in pieces of the ovary that were implanted, or from the layer of epithelial cells forming the outer coating of the adductor muscle, which might be carried inwards by the transplanting needle.

It thus appears that the conversion of fibroblasts into ciliated epithelium is a specific reaction following the implantation of the ripe living ovary.

These observations were the result of nearly a thousand experiments, of which the majority were performed on Pecten opercularis.

It appears that this conversion into ciliated epithelium of the inner layer of fibroblasts lining a cyst formed round a piece of the ovary, which has been implanted into the adductor muscle of Pecten, is a specific reaction that occurs only when the ripe living ovary of an animal of the same species is implanted. The reaction takes place long after all trace of organized structure in the implanted tissue has disappeared, and it is difficult to conceive of its being due to any other cause than the presence of some definite chemical substance within the cyst, which is characteristic of, and specific for, each species.

Examination of the contents of the cysts showed, in all cases where the development of ciliated epithelium had occurred, that an orange granular substance, and blood corpuscles in various stages of degeneration, were present. These orange granules resembled in appearance the orange-coloured yolk substance of the ripe ova, and the amount of this granular substance within the cysts seemed to be independent of the length of time during which the implanted tissue was allowed to remain in the muscle. If implantation of pieces of the ovary of approximately equal size were made, examination of the contents of a cyst after six days showed as much of this substance present as in a similar cyst after 120 days; hence it appears that this substance cannot escape through the cyst wall. When it is considered that the development of the ciliated epithelial lining only occurs as a reaction to the implantation of ripe ova, containing a plentiful supply of the orange-coloured yolk substance, there is at least a possibility that the orange substance within the cysts bears a close chemical relation to the yolk substance, and that the development of ciliated epithelium from the fibroblasts lining the cyst is a specific reaction to its presence.

Though admittedly based on no experimental evidence, it is suggested as a possible explanation of the phenomena that some substance is formed as a result of the ingestion of these orange granules by the blood corpuscles, and their subsequent degeneration within the cyst: that the granules themselves remain unchanged, and are again 
set free on the disintegration of the corpuscles, and that their action on the protoplasm of the corpuscles is merely catalytic. This substance, produced from the blood corpuscles, is probably a fluid, and would be slowly and continuously formed as long as blood corpuscles could pass through the walls of the cyst. The action of this substance on the fibroblasts forming the walls of the cyst is to delay their return to the spindle shape typical of the resting condition, and eventually to set up those changes in the.inner layer of fibroblasts resulting in their conversion into ciliated epithelium.

G. H. D.

\section{A Review of the British Marine Cercariae. By Marie V. Lebour,} MI.Sc. (Parasitology, Vol. IV, No. IV, January, 1912.)

THE work in this paper on Spelotrema excellens Nicoll was partly carried out at Plymouth in April, 1911. The first host of this worm seems most commonly to be Littorina obtusata; L. rudis and Paludestrina stagnalis are also first hosts for it. The tailed cercaria occurs in sporocysts in the digestive gland of these molluscs, and possesses a stylet in its head by which presumably it bores its way into its second host, the green crab, Carcinus maenas. Here it encysts and gradually enlarges, loses its stylet, and assumes the Spelotrema form, the walls of the cyst thickening until a certain size is reached, when the cercaria rests. The full-grown cysts are found all the year round, but no young stages in the winter. All the Plymouth crabs seem to be infected and in almost every organ, the digestive gland and muscles being the favourite parts. The final host of the worm is probably the herring gull, Larus argentatus.

M. V. L.

Contributions to the Knowledge of the Laminarias. (Beiträge zur Kenntnis der Laminarien.) By C. Killian. (Zeitschrift für Botanik, 1911, Heft 7.)

Notwithstanding the large number of papers on Laminaria, its development was until recently but little understood, for it was only in 1910 that Drew published an account of the first successful cultures. Thanks to the previous work of that author, the writer 
succeeded in getting the swarm spores of Laminaria digitata to germinate. First of all there developed a germinal thread consisting of a few cells; from certain of these cells secondary, one-layered laminae sprouted, which were joined to the germinal thread by colourless rootlet cells. Later these rootlet cells disappeared, and then the laminae, freed from the germinal threads, developed on their lower sides rhizoids which established a direct attachment to the rocks. In the young plants the cell divisions proceed at first regularly over the whole surface. It is only later that the intercalary growing point is formed between the rhizoids and the leaf; in addition growth tissue develops at the edge of the leaf and makes the extension of the surface in breadth possible. Gradually the young plant becomes manylayered; the outer layers consist of isodiametric, the innermost of elongated cells with rich intercellular substance; only the point remains for the time one-layered. It must, however, be noted that in the stalk the rows of newly formed central tissue remain near together; in the leaves, on the other hand, where the growth in breadth strongly predominates, the original longitudinal rows become more and more pulled asunder. A further complication is added, in that (1) between these rows of the internal tissue connections already existed which are now simply mechanically pulled apart, and (2) new connections of this kind are formed. These new connections occur through two cells, which develop at opposite points on the longitudinal rows, growing towards one another and becoming fused. From a cell resulting from such fusion a chain of cells then forms by transverse division. In still later stages the single cells of the longitudinal and transverse rows of the central tissue, whose power of growth ceases, become mechanically deformed through the rapid growth of the leaf. In this way there finally result tube-shaped cells which, according to their age and the degree of the tension to which they are subjected, differ from one another in appearance. We can thus understand the confused mass of cells of all possible shapes which is presented by a section through the central tissue of an old plant. Similar pictures such as one finds in other Laminarias suggest that in them also tissue development takes the same course.

A point in the anatomy of the haptera is worth noting, viz., that in these there are internally no elongated, tube-shaped cells. As is well known, these algae possess at first an adhesive dise from which the organs of attachment take origin, the construction and shape of the latter being modified by external conditions.

It is well known that the different representatives of the Laminariae are characterized by regularly split leaves. In order to understand 
the processes which bring about the formation and the repair of these slits, experiments were undertaken by the author with a view to explaining the reactions and tissue-formations which follow as the result of wounding. It was shown that Laminaria digitata after being wounded reacted rapidly and vigorously. The differentiation in the stem, leaf, and haptera, the age and the corresponding specialization of the tissue cause manifold differences in the regeneration, and the direction and character of the wound also exert an influence. As regards the tearing process, which may be especially well seen in Laminaria hyperborea, it appeared that these plants slit their leaves autonomously. This is made clear by a microscopical investigation of the leaf surface in the neighbourhood of such a tear. The epidermis at such a place bends inwards from both leaf faces more and more into the inner tissue. One cannot, be it noted, speak of any external wounding. When the epidermis has forced itself in this way into the central tissue the latter finally becomes torn and the further growth of the epidermis closes the wound. From this normal slit-formation and healing we must distinguish the purely mechanical splitting, which heals in exactly the same way as the wounds in the experiments already mentioned. In nature both kinds of slit-formation run into one another. In other Laminarias a similar state of things seems to exist.

Field observations show that Laminarias have definite requirements as to light, heat, salinity, change of water, etc., at each different age. Differences in the external form of the different parts of the thallus clearly depend upon changes in these conditions. Laboratory experiments showed that Laminarias from different localities in the neighbourhood of Plymouth possessed different degrees of elasticity, and algae from places where wave movement was slight were stretched, with one and the same load per unit area of section, to a greater extent than the more resistant individuals from very exposed localities. Plants which grew under similar conditions showed, on the contrary, an equal degree of extension. Laminaria digitata stretched similarly to $L$. saccharina, whilst the surf-loving species $L$. hyperborea and bulbosa were more resistant.

K. 
Notes on the Choanoflagellate Genera Salpingoeca and Polyoeca, with Description of Polyoeca dumosa, sp. n. By J. S. Dunkerly, B.Sc. (Annals Mag. Nat. Hist., Ser. 8, Vol. V, Feb, 1910, pp. 186-191.)

Note on our Present Knowledge of the Choanoflagellata. By J. S.

Dunkerly, B.Sc. (Journ. Quekett Micr. Club, April, 1910, pp. 19-24.)

THE following is a summary of observations on some Flagellata at Plymouth Marine Biological Station during the month of August, 1909.

Certain late division stages of Salpingoeca vaginicola and the setting free of the daughter cell were observed, and a new species of Polyoeca, $P$. dumosa, was described from material taken from a tank in the Laboratory, the type species, $P$. dichotoma S. K. not having been recorded since 1874 . The above results were described with figures in Ann. and Mag. Nat. Hist., Ser. 8, Vol. V, 1910, and in addition to the above, the following species of Choanoflagellidae were found:-

Codonosiga botrytis J. Cl.

Codonocladium umbellatum Tat.

Salpingoeca vaginicola St.

, ampulla S. K.

", urceolata S. K.

Polyoeca dumosa n. sp.

Although careful search was made, none of the double-collared forms, Diplosiga Frenz. or Diplosigopsis Francé, were found, and I have been unable to find these in material from many different localities. That another interpretation than that of a double collar may be placed upon some of the published figures of these forms I have pointed out in another place (Journ. Quekett Microsc. Club, Ser. 2, Vol. XI, 1910). 